\title{
Kampanye Moderasi Beragama di Facebook: Bentuk dan Strategi Pesan
}

\author{
Ari Wibowo \\ Fakultas Dakwah dan Komunikasi \\ IAIN Syaikh Abdurrahman Siddik Bangka Belitung, Indonesia \\ ari@iainsasbabel.ac.id
}

\begin{abstract}
This paper seeks to formulate an ideal concept in campaigning for religious moderation in Indonesia through the use of Facebook. There are three things that underlie this study, 1) The mass movement of radicalism in the name of religion in Social Media; 2) Potential conflicts on the basis of SARA; 3) The importance of efforts to strengthen religious moderation in Indonesia based on social media. The idea of religious moderation must be strengthened by the national movement. The library research method (library study) becomes the scientific foundation for exploring various literature, both primary and secondary related to the concept of religious moderation in Indonesia. The results of this study offer a message form and strategy in campaigning for religious moderation on Facebook. First, the form of a religious moderation campaign on Facebook must be ideologically-oriented (oriented towards changing attitudes, behavior and public views). Second, campaign messages must be informative and persuasive (based on data and facts) and can influence other Facebook users to participate in creating campaigns (social campaigns) on religious moderation. A religious moderation campaign message on Facebook does not necessarily have to content writing, it can also be an illustrative (animated) picture or a short educational video
\end{abstract}

Keywords: Religious Moderation, Radicalism, Campaigns, Social Media, Facebook

\begin{abstract}
Abstrak
Tulisan ini berupaya merumuskan konsep ideal dalam mengkampanyekan moderasi beragama di Indonesia melalui pemanfaatan Facebook. Ada tiga hal yang mendasari kajian ini, 1) Massifnya gerakan radikalisme atas nama agama di Media Sosial; 2) Potensi konflik atas dasar SARA; 3) Pentingnya upaya memperkuat moderasi beragama di Indonesia berbasis media sosial. Gagasan moderasi beragama tersebut harus diperkuat dengan gerakan Nasionl. Metode library research (studi pustaka) menjadi landasan
\end{abstract}


ilmiah untuk mengeksplorasi berbagai literatur, baik primer atau sekunder yang terkait konsep moderasi beragama di Indonesia. Hasil dari kajian ini menawarkan bentuk dan strategi pesan dalam mengkampanyekan moderasi beragama di Facebook. Pertama, bentuk kampanye moderasi beragama di Facebook harus bersifat ideologically-oriented (berorientasi pada perubahan sikap, perilaku dan pandangan publik). Kedua, Pesan kampanye harus informatif dan persuasif (didasari data dan fakta) serta dapat mempengaruhi pengguna Facebook lainnya untuk ikut membuat kampanye (social campaign) tentang moderasi beragama. Pesan kampanye moderasi beragama di Facebook tidak mesti harus berisi tulisan, dapat juga berupa gambar (animasi) ilustratif atau video edukasi berdurasi pendek.

\section{Kata Kunci: Moderasi Beragama, Radikalisme, Kampanye, Media Sosial, Facebook}

\section{A. Pendahuluan}

Munculnya gerakan moderasi beragama tidak terlepas dari meluasnya ancaman radikalisme dalam beragama di Indonesia. Gagasan ini muncul untuk menangkal gerakan radikalisme dalam beragama yang semakin meluas. Radikalisme dalam beragama tersebut muncul karena ekspresi agama yang seringkali diperankan secara radikal. Kekerasan dan kebencian atas nama Tuhan atau agama seolah menjadi paham yang mengakar dan sulit terobati. Harus disadari bahwa tindakan radikalisme dalam beragama masuk dalam ranah teologis. Sebagaimana diungkap Jhon L. Esposito bahwa kekerasan dan peperangan atas nama agama didasari oleh kerasnya doktrin keagamaan yang diterima oleh seseorang. ${ }^{1}$

Agama sebagai pusat spiritual sejatinya menjadi pemersatu yang mendamaikan umat manusia, bukan menjadi penyebab perpecahan. Seringkali agama dipolitisasi dengan maksud memaksa munculnya pemahaman yang sama terhadap ajaran agama, sehingga berkembang sikap eksklusif. ${ }^{2}$ Akhirnya menimbulkan pertentangan dan perpecahan antar umat beragama. Mas'ud Halimil dalam rapat koordinasi penanggulangan radikalisme yang dilaksanakan oleh Badan Nasional Penanggulangan Terorisme (BNPT) menyebutkan bahwa, pemahaman keagamaan masyarakat ada pada level "waspada" (66,3\%). Sedangkan pada kalangan mahasiswa berada pada level "hati-hati" $(20,3 \%){ }^{3}$

${ }^{1}$ Jhon L. Esposito, Unholy War:Teror Atas Nama Islam (Yogyakarta: Ikon, 2003), p.30

${ }^{2}$ Emna Laisa, "Islam dan Radikalisme", Jurnal Islamuna, vol. 1 no. 1 (2014), p. 2

${ }^{3}$ Subdit Sarpras dan Kemahasiswaaan, "BNPT: Hati-hati radikalisme di kalangan Mahasiswa capai angka 20,3\%, Direktorat Pendidikan Tinggi Keagamaan Islam (25 Nov 2013) https://diktis.kemenag.go.id/NEW/index.php?berita=detil\&jenis=news\&jd=162, diakses 13 Nov 2019. 
Penyebaran pemahaman keagamaan yang ekslusif tersebut meluas melalui media sosial. Kemudahan dan kecepatan akses yang ditawarkan media sosial menjadi ruang gerak yang bebas bagi para radikalis mendoktrinasi kalangan pemuda. ${ }^{4}$ Sebagai contoh munculnya akun "Muslim Cyber Army Indonesia (MCAI)" yang terindikasi sebagai produk radikalisme agama. Terbukti dari pernyataan Ramdhani salah satu anggota MCAI yang mengungkapkan bahwa mereka punya jadwal perang di media sosial. Sebelum memulai perang, para anggota MCAI terlebih dahulu masuk dan memantau beberapa grup di media sosial. ${ }^{5}$

Berdasarkan laporan Direktorat Pengendalian Aplikasi Informatika Ditjen Aplikasi Informatika Kementerian Kominfo, menunjukkan bahwa konten yang terbanyak diblokir berada di Facebook dan Instagram, yakni sebanyak 8.131 konten. Sedangkan, di Twitter sebanyak 1.384 konten. Adapun konten radikalisme dan terorisme yang diblokir di Google dan YouTube sebanyak 678 konten. Kemudian, 614 konten di platform Telegram, 502 konten yang berada di file sharing, dan 494 konten di situs web. ${ }^{6}$

Tabel 1.

DATA PENANGANAN KONTEN RADIKALISME TERORISME 2017 - 2019

\begin{tabular}{|c|c|c|c|c|c|c|c|}
\hline Bulan, Tahun & Situs & $\begin{array}{c}\text { File } \\
\text { Sharing }\end{array}$ & Telegram & $\begin{array}{l}\text { Google I } \\
\text { Youtube }\end{array}$ & Twitter & $\begin{array}{l}\text { Facebook / } \\
\text { Instagram }\end{array}$ & Total \\
\hline$<=2017$ & 202 & 0 & 112 & 1 & 0 & 8 & 323 \\
\hline Januari 2018 & 0 & 0 & 0 & 0 & 0 & 0 & 0 \\
\hline Februari 2018 & 0 & 0 & 0 & 0 & 0 & 0 & 0 \\
\hline Maret 2018 & 1 & 0 & 0 & 0 & 0 & 0 & 1 \\
\hline April 2018 & 34 & 0 & 0 & 21 & 14 & 597 & 666 \\
\hline Mei 2018 & 102 & 415 & 502 & 551 & 555 & 2017 & 4142 \\
\hline Juni 2018 & 27 & 84 & 0 & 1 & 334 & 1084 & 1530 \\
\hline Juli 2018 & 4 & 0 & 0 & 4 & 273 & 760 & 1041 \\
\hline Agustus 2018 & 58 & 0 & 0 & 2 & 18 & 3 & 81 \\
\hline September 2018 & 23 & 1 & 0 & 12 & 23 & 11 & 70 \\
\hline Oktober 2018 & 39 & 1 & 0 & 12 & 35 & 1116 & 1203 \\
\hline November 2018 & 2 & 1 & 0 & 0 & 16 & 722 & 741 \\
\hline Desember 2018 & 2 & 0 & 0 & 74 & 48 & 850 & 974 \\
\hline Januari 2019 & 0 & 0 & 0 & 0 & 26 & 554 & 580 \\
\hline Februari 2019 & 0 & 0 & 0 & 0 & 42 & 409 & 451 \\
\hline \multicolumn{7}{|c|}{ Grand Total } & 11803 \\
\hline
\end{tabular}

${ }^{4}$ Leni Winarni, "Media Massa dan Isu Radikalisme Islam”, Jurnal Komunikasi Massa, vol.7 no.2 (2014), p. 164-165.

5 Rengga Sancaya, “Anggota Muslim Cyber Army Ungkap Jadwal Perang Mereka di Medsos”, DetikNews (11 Mar 2018), https://news.detik.com/berita/d-3910139/anggota-muslim-cyber-armyungkap-jadwal-perang-mereka-di-medsos, diakses 13 Nov 2019.

${ }^{6}$ Fernandus Setu, "Kominfo Blokir 11.803 Konten Radikalisme dan Terorisme", Kementerian Komunikasi dan Informatika Republik Indonesia (15 Mar 2019), https:// kominfo.go.id/content/detail/17274/siaran-pers-no-63hmkominfo032019-tentang-kominfo-blokir11803-konten-radikalisme-dan-terorisme/0/siaran_pers, diakses pada 14 Nov 2019 
Semakin jelas bahwa pengarusutamaan moderasi beragama harus menjadi gerakan yang dilaksanakan secara sinergis dan massif di media sosial khususnya Facebook. Pertanyaannya, seperti apa bentuk atau model dan strategi pesan yang tepat dalam mengkampanyekan gerakan moderasi beragama di media sosial, khususnya media facebook? Untuk itu tulisan ini berupaya mengkaji berbagai literatur untuk dijadikan dasar dalam mengkonsepsi bentuk dan strategi pesan yang tepat dalam mengkampanyekan moderasi beragama di Indonesia.

\section{B. Konsep Moderasi Beragama di Indonesia}

Dalam bahasa Arab moderasi dikenal dengan istilah al-wasathiyah yang berasal dari kata wasath. Dalam penjelasannya Ibnu Asyur secara rinci mendefinisikan kata wasath dalam dua aspek. Pertama, wasath menurut etimologi berarti sesuatu yang ada ditengah-tengah atau sesuatu yang memiliki dua belah ujung yang ukurannya seimbang. Kedua, definisi menurut terminologi yang berarti adalah nilai-nilai Islam yang terbentuk atas dasar pemikiran yang lurus dan pertengahan serta cenderung tidak berlebihan dalam hal tertenu. ${ }^{7}$

Begitu juga Al Asfahany mengartikan makna wasath yaitu tengah-tengah diantara dua batas, atau dengan keadilan yang tengah-tengah. Washatan juga bermakna menjaga dari bersikap tanpa kopromi bahkan meninggalkan garis kebenaran agama. ${ }^{8}$ Tholhatul Choir mengutip Merriam Webster Dictionary memberi garis besar bahwa moderasi adalah tindakan atau perilaku yang menjauhi perbuatan ekstrem. Seseorang yang moderat menurutnya ialah mereka yang menjauhi perilaku-perilkau dan ungkapan ekstrem. ${ }^{9}$ Lebih lanjut Khaled Abu el Fadl dalam The Great Theft memiliki pandangan yang sama tentang moderasi yaitu paham yang tidak ekstrem kanan dan tidak pula ekstrem kiri. ${ }^{10}$

${ }^{7}$ Rizal Ahyar Mussafa, Konsep Nilai-nilai Moderasi dalam Al-Qur'an dan Implementasinya dalam Pendidikan Agama Islam (Analisis al-Qur'an surat al-Baqarah 143), Skripsi (Fakultas Ilmu Tarbiyah dan Keguruan Universitas Islam Negeri Walisongo Semarang: 2018), p. 20. Lihat juga Ibnu, Asyur, at-Tahrir Wa at-Tanwir, (Tunis: ad-Dar Tunisiyyah, 1984), p. 17-18.

${ }^{8}$ Al-Alamah al-Raghib al-Asfahaniy, Mufradat al-Fadz al-Qur"an (Beirut: Darel Qalam, 2009), p. 869.

9 Tholhatul Choir, Ahwan Fanani, dkk, Islam Dalam Berbagai Pembacaan Kontemporer, (Yogyakarta: Pustaka Pelajar, 2009), p. 468.

${ }^{10}$ Ibid., p, 467 
Dalam konteks ke-Indonesiaan istilah moderasi beberapa tahun terakhir begitu sangat populer, bahkan Pemerintah Indonesia melalui Kementerian Agama RI membuat sebuah gagasan pemikiran dan gerakan yang dikenal dengan moderasi beragama. Bahkan pada 08 Oktober 2019 Menteri Agama Lukman Hakim Syaifudin merilis buku moderasi beragama. Menurutnya ada tiga hal yang menjadi tolok ukur moderasi beragama. Pertama, kembali pada inti pokok ajaran agama, yaitu nilai kemanusiaan. Setiap agama, inti pokok ajarannya mengajak untuk menghargai dan melindungi harkat dan martabat kemanusiaan. "Bila ada ajaran agama yang bertolak belakang dengan inti ajaran pokok agama maka ini sudah berlebihan dan ekstrem". ${ }^{11}$

Jauh sebelumnya KH Abdurrahman Wahid merumuskan bahwa moderasi harus mampu mendorong upaya mewujudkan keadilan sosial yang merata dan seimbang. Dalam perspektif agama dikenal dengan istilah al-maslahah al-'ammah. Oleh karena itu dalam aspek kenegaraan dan kebangsaan moderasi beragama di Indonesia harus mampu menjadi pondasi kebijakan publik, sehingga setiap pemimpin mempunyai tanggung jawab moral yang tinggi untuk menerjemahkan esensi agama dalam ruang publik. ${ }^{12}$

Gagasan besar moderasi beragama di Indonesia diusung atas berbagai persoalan bangsa yang semakin besar. Indonesia sebagai negara yang besar dan memiliki keragaman etnis, suku, budaya, bahasa dan agama dibanding negara lain di dunia, memiliki potensi perbedaan persepsi dan konsepsi yang sangat tinggi. Hingga tak dapat dipungkiri gerakan radikalisme dan terorisme atas nama agama/jihad menyebar luas mendoktrinasi masyarakat. Radikalisme atau kekerasan dalam konteks moderasi beragama dipahami sebagai suatu ideologi yang bertujuan merubah tatanan sistem sosial dan politik dengan cara yang ekstrem dengan dalih agama. ${ }^{13}$

Ada banyak kasus yang terjadi dengan mengatasnamakan agama, kasus terakhir yang menguat terjadi pada tahun 2018 tepatnya pada Mingu 13 Mei 2018 dan Senin 14

\footnotetext{
${ }^{11}$ Noor Hidayat Kurniawan, "Menag Luncurkan Buku Moderasi Beragama" (08 Okt2019), Direktorat Jenderal Bimbingan Masyarkat Islam (Bimas Islam), https://bimasislam.kemenag.go.id/post/berita/menag-luncurkan-buku-moderasi-beragama, diakses pada 15 Nov 2019.

${ }^{12}$ Zuhairi Misrawi, Hadratussyaikh Hasyim Asy'ari Moderasi, Keutamaan, dan Kebangsaan (Jakarta: Kompas Media Nusantara, 2010), p.13.

${ }^{13}$ Kementerian Agama RI, Moderasi Beragama (Jakarta: Badan Litbang dan Diklat Kementerian Agama RI, 2019), p. ii
} 
Mei 2018 tentang rangkaian bom bunuh diri di berbagai tempat. ${ }^{14}$ Kejadian ini dapat menstimuli munculnya kejadian serupa seperti fenomena gunung es. Tindakan radikal dan teror atas nama agama seringkali dinilai atas dasar jihad fisabilillah. Makna jihad oleh kelompok mereka dipahami secara literalis-tekstualis. Pemahaman seperti inilah yang berimplikasi pada sikap dan perilaku sosial keagamaan. ${ }^{15}$

Wahid Foundation pada tahun 2016 memaparkan hasil survei Nasional tentang Potensi Intoleransi dan Radikalisme Sosial-Keagamaan di Kalangan Muslim Indonesia. Ditemukan data sebanyak 108 juta Muslim Indonesia tidak radikal, sekitar 11 juta Muslim Indonesia bersedia radikal, dan 600 ribu muslim Indonesia pernah terlibat tindakan radikal. Potensi radikalisme sosial-keagamaan adalah kesediaan berpartisipasi dalam peristiwaperistiwa yang melibatkan kekerasan atas nama agama. ${ }^{16}$

Syamsul Bakri melihat ada beberapa faktor yang mendorong munculnya gerakan radikalisme di Indonesia. Pertama, faktor sosial politik hal ini terlihat dari kekerasan agama yang muncul lebih banyak didasari atas gejala politik dan sosial, bukan atas dasar gejala keagamaan yang sebenarnya. Dipertegas Azyumardi Azra bahwa memburuknya posisi negara-negara muslim dan konflik utara-selatan menjadi pendorong utama munculnya radikalisme. ${ }^{17}$ Kedua, faktor emosi keagamaan, yaitu rasa solidaritas yang tinggi terhadap saudara seiman yang tertindas oleh kelompok tertentu. Kelompok atau gerakan yang muncul atas nama agama secara terang-terangan memperlihatkan emosi kemarahan yang didasari penafsiran yang salah terhadap kasus keagamaan yang timbul.

Ketiga, faktor kultural. Faktor ini menjadi sentimen yang khas karena Indonesia memiliki tingkat konflik kebudayaan yang tinggi. Kelompok yang mengatasnamakan agama seringkali menjadikan aspek tradisi dan budaya sebagai alat untuk memisahkan konsep agama dan budaya. Tradisi budaya yang tidak sesuai dengan pemahaman keagamaan mereka harus dihilangkan. Seperti diungkap Musa Asya'ari bahwa ada usaha-

\footnotetext{
${ }^{14}$ Kompas, "Inilah Deretan Aksi Bom Bunuh Diri di Indonesia," KOMPAS.com (14 Mei 2018), https://nasional.kompas.com/read/2018/05/14/13533731/inilahlmderetan-aksi-bom-bunuhdiri-di-indonesia, diakses pada 18 Nov 2019.

15 Kasinyo Harto, "Pengembangan pembelajaran PAI Berwawasan Islam Wasatiyah: Upaya Membangun Sikap Moderasi Beragama Peserta Didik”, Jurnal At-Ta'lim Media Informasi Pendidikan Islam, vol.18 no.1, 2019, p. 89-110

${ }^{16}$ Wahid Foundation, Paparan Hasil Surveri Nasional: Potensi Intoleransi dan Radikalisme Sosial-Keagamaan di kalangan Muslim Indonesia, Tahun 2016.

${ }^{17}$ Syamsul Bakri, "Islam dan Wacana Radikalisme Agama Kontemporer," Jurnal DINIKA, vol. 3 no. 1 , (2004), p. 10-12
} 
usaha kelompok masyarakat memisahkan konteks budaya dengan agama. ${ }^{18}$ Keempat, faktor ideologis anti westernisasi. Simbol-simbol yang berasal dari pemikiran tokoh Barat harus dihancurkan demi penegakan syari'at Islam.

Kelima, faktor kebijakan pemerintah. Seringkali kebijakan pemerintah tidak mampu memperbaiki berkembangnya frustasi dan kemarahan umat yang disebabakan faktor ideologi, militer, dan perkembangan ekonomi dari negara-negara besar. ${ }^{19}$ Kenyataan inilah yang mendesak pemerintah Indonesia segera mengambil sikap tegas terhadap upaya moderasi beragama.

Ada banyak upaya strategis pemerintah dalam mengkampanyekan gerakan moderasi beragama di Indonesia. Salah satunya melalui institusi pendidikan. Dalam buku yang diterbitkan Maarif Institut ada tiga pintu utama pemahaman radikal masuk di lingkungan sekolah, diantaranya; 1) kegiatan ektrakurikuler; 2) peran guru dalam proses belajar mengajar; 3 ) lemahnya kebijakan sekolah dalam mengontrol paham radikal. ${ }^{20}$

\section{Potret Kajian Moderasi Beragama di Indonesia}

Lahirnya gagasan moderasi beragama di Indonesia menjadi daya tarik bagi berbagai kalangan cendikiawan. Seminar nasional bahkan international yang diselenggarakan oleh institusi pendidikan di Indonesia menawarkan tema moderasi beragama sebagai muatan utama yang disajikan. Sebagai contoh terbitnya buku "Moderasi Beragama: Jihad Ulama Menyelamatkan Umat dan Negeri dari Bahaya Hoax.” Terbitnya buku ini muncul dari hasil kegiatan "Mudzakarah Ulama Kharismatik Banten" yang dilaksanakan oleh Yayasan Benteng Nusantara Cendikia Nahdlatul Ulama.

Para ulama Banten dalam kajiannya menilai bahwa adanya suguhan politik yang tidak sehat dan tidak bernilai, bahkan mengarah pada penyesatan umat ditinjau dari sisi agama. Dalam konteks media, masyarakat sebagai penerima informasi belum mampu membedakan informasi yang benar dan salah. ${ }^{21}$ Selanjutnya Kementerian Agama Republik Indonesia melalui Badan Litbang dan Diklat Kementerian Agama menerbitkan "Buku Moderasi Beragama”. Buku ini merupakan hasil dari sejumlah tahapan berfikir

${ }^{18}$ Ibid., p. $10-12$

${ }^{19}$ Ibid., p.13

20 Dirga Maulana, "Ruang Moderasi Beragama", Media Indonesia (21 Jan 2019) https://mediaindonesia.com/read/detail/211781-ruang-moderasi-beragama, diakses 15 Nov 2019.

21 Muhammad Qustulani, Fahmi Irfani, dkk, Moderasi Beragama: Jihad Ulama Menyelamatkan Umat dan Negeri dari Bahaya Hoax (Tangerang: PSP Nusantara: 2019), p. ii 
ilmiah dan melibatkan peneliti dari Badan Litbang dan Diklat serta Pusat Pengkajian Islam dan Masyarakat (PPIM) Universitas Islam Negeri (UIN) Jakarta. Buku ini banyak mengupas tenang apa (what), mengapa (why), dan bagaimana (how) terkait moderasi beragama. Ada tiga aspek utama yang dikedepankan dalam buku ini, yakni kajian konseptual moderasi bergama, pengalaman empirik moderasi beragama, serta strategi penguatan dan implementasi moderasi beragama. ${ }^{22}$

Diperkuat oleh Muchlis Hanafi dalam bukunya Moderasi Islam: Menangkal Radikalisasi Berbasis Agama yang menekankan bahwa ada kecenderungan ekstrem yang ditunjukkan umat Islam yakni sikap ketat dalam beragama, hingga cenderung menutup diri dan bersikap longgar dan terbuka sehingga membuat kabur esensi agama yang sebenarnya. ${ }^{23}$ Masyarakat harus mampu memahami makna moderasi Islam, artinya mampu bersikap moderat diantara berbagai perbedaan dalam memahami ajaran agama dan mulai mencerminkannya dalam kehidupan sehari-hari.

Selain itu, ada juga kalangan akdemisi yang melihat konsep moderasi beragama ditinjau dari perspektif Islam . Seperti Afrizal Nur dan Mukhlis yang melakukan kajian tentang "Konsep Wasathiyah dalam Al-Qur'an (Studi Kompartif Antara Tafsir At-Tahriri Wa At-Tanwir dan Aisar At-Tafsir). Dalam penelitiannya dijelaskan bahwa umat Islam harus mampu mengintergrasikan dimensi teocentris (hubungan manusia dengan Allah) dan dimensi antropocentris (hubungan manusia dengan manusia lainnya). Jangan terjebak pada makna wasathiyah yang diambil para ekstrimis dalam mengedepankan sikap keras tanpa kompromi (ifrath), atau pemahaman kelompok liberalis yang sangat longgar dalam menjelaskan ajaran agama. ${ }^{24}$

Selanjutnya penelitian yang dilakukan oleh Toto Suharto tentang "Indonesianisasi Islam: Penguatan Islam Moderat dalam Lembaga Pendidikan Islam di Indonesia". Menurutnya moderasi Islam adalah bagian dari warisan para Walisongo dalam menyebarkan ajaran Islam yang rahmatan lil 'alamin. Menurutnya umat Muslim Indonesia harus mengedepankan nilai moderasi Islam dalam hidup berbangsa, beragama,

${ }^{22}$ Kementerian Agama RI, Moderasi Beragama, p. Iii.

${ }^{23}$ Muchlis Hanafi, Moderasi Islam: Menangkal Radikalisasi Berbasis Agama (Jakarta: PSQ, 2013), p. 3.

${ }^{24}$ Afrizal Nur dan Mukhlis, "Konsep Wasathiyah dalam Al-Qur'an (Studi Kompartif Antara Tafsir At-Tahriri Wa At-Tanwir dan Aisar At-Tafsir", Jurnal An-Nur, vol.4 no. 2, (2015), p. 205-223. 
dan bernegara. Meskipun ada kelompok yang dianggap transnasional seperti; Ikhwanul Muslimin, Hizbut Tahrir, dan Wahabi Salafi. ${ }^{25}$ Perlu penguatan dalam lembaga pendidikan diantaranya; 1) penekanan Islam moderat dalam merumuskan tujuan pendidikan; 2) internalisasi nilai-nilai moderat dalam merancang bangunan kurikulum; dan 3) memfilterisasi materi ajar dari pemahaman radikal.

Kajian-kajian tersebut merupakan bagian penting dalam mendukung moderasi beragama di Indonesia secara berkesinambungan. Di satu sisi Kementerian Agama RI diharapkan menjadi garda terdepan dalam meningkatkan kajian dan studi tentang moderasi agama. Kajian itulah yang akan menjadi pilar dan strategi dalam mengimplementasikan nilai moderasi Islam di masyarakat dalam berbagai dimensi.

\section{Bentuk Kampanye Moderasi Beragama di Media Sosial (Facebook)}

Kemunculan media sosial (social media) telah membawa dampak yang signifikan bagi perkembangan budaya komunikasi dan interaksi masyarakat di ruang publik. Interaksi antar masyarakat tidak lagi terhubung secara nyata, tapi juga terhubung secara maya (artificial) melalui teknologi digital. Masyarakat nyata ialah kehidupan masyarakat yang secara inderawi terhubung secara langsung melalui interaksi sosial secara tatap muka. Sedangkan masyarakat maya ialah kehidupan masyarakat yang tidak dapat ditangkap oleh inderawi secara langsung, tetapi dapat dirasakan dan disaksikan sebagai sebuah realitas yang termediasi oleh teknologi digital. ${ }^{26}$

Konstruksi dunia maya itupun menciptakan interaksi komunitas digital (virtual community) yang saling terkoneksi di ruang siber (cyberspace) dengan sangat cepat. Istilah cyberspace untuk pertama kalinya diperkenalkan dalam sebuah novel yang dikarang oleh Venor pada tahun 1981. Lalu pada tahun 1984 kata cyberspace tersebut diadaptasi oleh Gibson dalam novelnya "Neuromancer". Lebih dalam Gibson mengartikan kata cyberspace adalah sekumpulan data representasi grafik demi grafik yang hanya bisa diakses melalui perangkat komputer. ${ }^{27}$

25 Toto Suharto, "Indonesianisasi Islam: Penguatan Islam Moderat dalam Lembaga Pendidikan di Indonesia”, Jurnal Al-Tahrir: Jurnal Pemikiran Islam, vol. 17, no.1 (2017), p. 155178.

${ }^{26}$ Yasraf Piliang, Bayang-Bayang Tuhan: Agama Dan Imajinasi (Bandung: Mizan Publika2011), P. 143

${ }^{27}$ Rulli Nasrullah, Komunikasi Antar Budaya Di Era Budaya Siber (Bandung: Simbiosa, 2012), p. 20 
Lebih lanjut cyberspace menjadi ruang bebas bagi masyarakat untuk membangun kehidupan artifisial (virtual life), sehingga menampilkan wajah baru kehidupan masyarakat menjadi masyarakat informasi dan digital. ${ }^{28}$ Masyarakat informasi (information society) ini memiliki karakteristik penggunaan media yang tinggi terhadap informasi diberbagai aspek baik sosial, pendidikan, dan bisnis. ${ }^{29}$ Terlihat dari pola penggunaan dan pemanfaatan berbagai platforms media sosial. ${ }^{30}$

\section{Gambar 1.}

Grafik plaltforms media sosial yang paling aktif pada tahun 2018

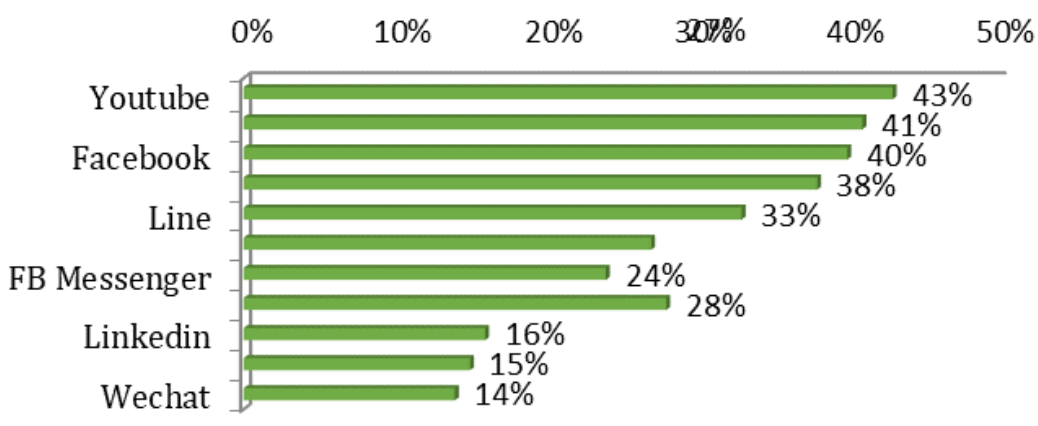

Dalam sejarahnya Facebook pada tahun 2004 pertama kali digunakan oleh mahasiswa Harvard. Pada tahun berikutnya Facebook telah digunakan di sekolah-sekolah Amerika, dan pada akhirnya dibuka untuk umum pada tahun 2006. Aktifitas Facebook di jejaring online pun akhirnya mengembangkan diri dengan berbagai fitur yang menarik. Pengguna dapat saling berkirim pesan, gambar, dan video. Bahkan dapat dijadikan sebagai media untuk kegiatan komersil seperti jual beli.

Para pengguna (user) juga dapat bergabung dalam grup komunitas sesuai dengan minatnya. Bisa berupa komunitas warga kota, lingkup kerja atau profesi dan pendidikan. Dikalangan remaja facebook sangat diminati bahkan membuat para remaja lupa waktu. ${ }^{31}$ Tragisnya kemudahan mengakses Facebook berdampak pada tingginya konten atau pesan

${ }^{28}$ Ibid., p. 23

${ }^{29}$ Reni Puspita Sari, "Pencapaian Masyarakat Informasi Ditinjau Melalui Implementasi Program Kelompok Informasi Masyarakat (Kim): Studi Kasus Implementasi Program Kim Di Jawa Timur Di Wilayah Rural (Kim Nglanduk Dan Kim Warurejo) Dan Wilayah Urban (Kim Mojo Dan Kim Swaraguna)", Jurnal Berkala Ilmu Perpustakaan dan Informasi, vol. 13, no. 1, (2017), p. 5663 ,

${ }^{30}$ Rulli Nasrullah, Etnografi Virtual (Bandung: Simbiosa, 2017), p. 23

${ }^{31}$ Hasnul Arifin, Nongkrong Asyik di Internet Dengan Facebook (Jakarta: Buku Kita, 2009), p. 19. 
radikal yang tersebar bebas melalui fitur posting. Tercatat sebanyak 7.160 konten di Facebook mengandung radikalisme dan terorisme. ${ }^{32}$

Akan tetapi Facebook juga dinilai mampu menjadi media yang tepat dalam mengkampanyekan moderasi beragama. Kampanye adalah salah satu bentuk komunikasi yang bersifat verbal dan nonverbal. Artinya pesan-pesan dapat disampaikan dalam berbagai bentuk, seperti; poster, spanduk, papan reklame, pidato, dan iklan diskusi. ${ }^{33}$ Umumnya istilah kampanye ini lebih bermuatan pada aspek komunikasi politik, dan banyak muncul menjelang pemilihan umum. Tetapi ada konsep penting dari kampanye yang dapat digunakan dalam berbagai aspek komunikasi. Seperti apa yang diuraikan Venus terkait elemen penting yang dapat mendukung kampanye moderasi beragama di Facebook, yang meliputi:

\section{The Intended Effect}

Sebelum menentukan elemen pendukung kampanye, efek yang diinginkan harus jelas, sehingga pencapainnya detil dan signifikan.

\section{Competing Communication}

Perlu memperkirakan potensi-potensi pengganggu jalannya kampanye, sehingga kampanye dapat terlaksana dengan efektif.

\section{The Communication Objective}

Perlu menetapkan tujuan jangka panjang agar kampanye terarah dan terukur.

\section{Target Population and The Receiving Group}

Target mengacu pada seluruh kelompok yang dilayani dalam program yang dirancang. Target populasi bersifat general denga berbagai karakteristik.

\section{The Channel}

Saluran komunikasi yang digunakan harus terkait dengan pesan dan keseharian kelompok penerima. Saluran yang akrab dan menyentuh kelompok penerima secara interpersonal.

\section{The Message}

\footnotetext{
${ }^{32}$ Kementerian Komunikasi dan Informatika Republik Indonesia, "BNPT: Internet jadi Media Penyebarluasan Terorisme", Kementerian Komunikasi dan Informatika RI (9 Mei 2019), https://kominfo.go.id/content/detail/18602/bnpt-internet-jadi-media-penyebarluasanterorisme/0/ berita_satker, diakses 20 Nov 2019.

${ }^{33}$ Antar Venus, Manajemen Kampanye, (Bandung: Simbiosa Rekatama Media, 2010), p. 31.
} 
Kampanye harus menyajikan pesan yang edukatif, informatif dan mempengaruhi perilaku sasaran. ${ }^{34}$

Kemudian Charles U. Larson dalam Ruslan membagi jenis kampanye sesuai fungsinya menjadi tiga jenis yaitu; 1) product-oriented; 2) candidate-oriented; dan 3) ideologically-oriented. $^{35}$ Dilihat dari substansinya maka jenis kampanye ini tepat digunakan untuk mengkampanyekan moderasi beragama di media sosial. Jenis kampanye ini mampu menangani berbagai masalah sosial di masyarakat melalui perubahan sikap, perilaku dan pandangan publik.

Lebih lanjut jenis kampanye tersebut perlu diperkuat dengan bentuk kampanye yang menggunakan interaksi simbolik. Konsep interaksi simbolik ini sesuai dengan pemikiran-pemikiran Mead, pemahaman yang ringkas dari tiga ide dasar interaksi simbolik adalah: pertama, mind (pikiran) yakni; kemampuan untuk mengorganisir simbol yang memiliki makna sosial yang sama. Artinya, setiap individu mengembangkan pikiran mereka dalam proses interaksi dengan individu lainnya. ${ }^{36}$ Kedua, self (diri pribadi) yakni; kemampuan untuk memahami diri tiap individu dari perspektif atau pendapat orang lain, dan teori interaksionisme simbolis merupakan cabang dari teori sosiologi yang mengupas studi tentang diri sendiri (self) dan dunia luarnya (life society). Ketiga, society (masyarakat) yakni; interaksi sosial yang diorganisir oleh setiap individu di masyarakat dan mereka melibatkan dirinya secara aktif, sehingga ikut berperan di tengah masyarakatnya. ${ }^{37}$

Oleh karena itu, proses kampanye moderasi beragama di Facebook dapat dilakukan oleh siapapun baik bersifat individual atau komunitas online. Sudah semestinya pengguna Facebook (user) ikut serta menjadi agen yang siap mengkampanyekan moderasi beragama di Facebook, seperti halnya kampanye sampah plastik, kampanye stunting, dan lain sebagainya.

\footnotetext{
${ }^{34}$ Antar Venus, Manajemen Kampanye: Panduan Teoritis dan Praktis dalam Mengefektifkan Kampanye Komunikasi (Bandung: Simbiosa Rekatama, 2004), p. 35.

${ }^{35}$ Rosady Ruslan, Manajemen Public Relatoins \& Media Komunikasi (Jakarta : Raja Grafindo Persada, 2008), p. 25-26.

${ }^{36}$ Rohayati, "Proses Komunikasi Masyarakat Cyber Dalam Perspektif Interaksi Simbolik", Jurnal RISALAH, vol. 28, no. 1 (2017), p. 43-54. 195.
} 
Ada beberapa potret kampanye moderasi beragama di Facebook, namun tidak menyentuh pada aspek ideologically-oriented. Apabila diketik keyword "Moderasi Beragama" pada laman cari, maka hanya sedikit akun yang mempublish gagasan moderasi beragama. Seperti pada gambar berikut:

Gambar 2.

Potret kampanye moderasi beragama di Facebook

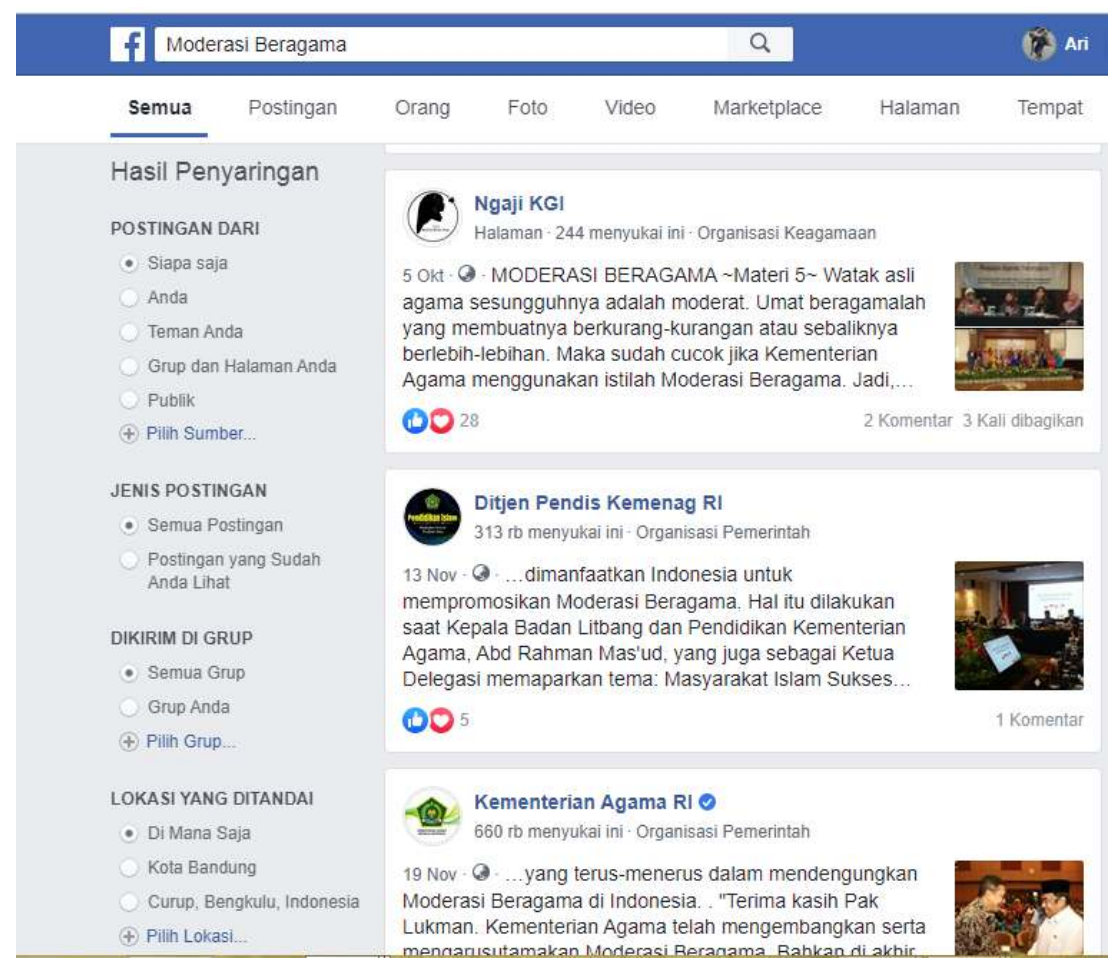

Akun Facebook tersebut menarasikan berita kegiatan moderasi agama, tapi tidak dalam bentuk kampanye moderasi beragama yang diinginkan. Lalu bagaimana seharusnya? Para pengguna dapat membuat video pendek atau poster yang bermuatan nilai-nilai moderasi beragama, sehingga simbol-simbol moderasi beragama tersebut dapat mudah diterima oleh pengguna Facebook yang lain.

\section{E. Strategi Pesan Kampanye Moderasi Beragama di Facebook}

Dalam proses kampanye, pesan menjadi unsur yang sangat penting dalam menunjang keberhasilan komunikasi. Pesan tersebut dapat berbentuk tulisan maupun lisan, yang di dalamnya berisi simbol-simbol atau lambang-lambang yang disepakati 
maknanya. ${ }^{38}$ Pratikno juga menguraikan bahwa pesan adalah semua bentuk komunikasi yang bersifat verbal maupun nonverbal. Verbal artinya komunikasi melalui lisan dan nonverbal berarti komunikasi dengan simbol, isyarat, sentuhan perasaan dan penciuman. ${ }^{39}$

Ada tiga faktor menurut Hanafi yang harus dipertimbangkan dalam pesan yaitu; 1) kode pesan yaitu, serangkaian simbol yang tersusun dan bermakna bagi orang lain; 2) materi pesan yaitu, bahan yang dipilih oleh komunikator untuk menyampaikan maksudnya; dan 3) wujud pesan yaitu, sesuatu yang membungkus inti pesan agar komunikan tertarik pada isi pesan yang ada di dalamnya. ${ }^{40}$ Dilihat dari bentuknya A.W Widjaja membagi bentuk pesan menjadi tiga yaitu;

1. Pesan Informatif

Pesan ini berisi keterangan fakta dan data, atas dasar itu komunikan mengambil keputusan dan kesimpulan sendiri. Pesan informatif disaat tertentu menjadi sangat penting dan berarti.

2. Pesan Persuasif

Pesan ini berisi bujukan dan rayuan yang membangkitkan pengertian dan kesadaran manusia bahwa apa yang disampaikan akan merubah sikap seseorang.

\section{Pesan Koersif}

Pesan ini bersifat memaksa dan berbentuk perintah dengan sanksi-sanksi. Pesan ini memberikan penekanan yang menumbuhkan tekanan batin dan ketakutan di kalangan publik. ${ }^{41}$

Lebih jelasnya Siahan juga menguraikan bahwa ada hal yang harus dipertimbangkan dalam mengemas pesan diantaranya sebagai berikut;

1. Clear

Pesan itu harus cukup jelas, artinya bahasa yang digunakan mudah dipahami, tidak berbelit-belit tanpa makna kiasan yang menyimpang dan tuntas;

2. Correct

\footnotetext{
${ }^{38}$ Onong Uchjana Effendi, Ilmu Komunikasi Teori dan Praktek (Bandung: Remaja Rosdakarya, 2002), p. 18.

${ }^{39}$ Pratikno, Globalisasi Komunikasi (Jakarta: Pustaka Sinar Harapan, 1987), p. 42.

${ }^{40}$ Siahaan, S. M., Komunikasi Pemahaman dan penerapannya (Jakarta: Gunung Mulia, 1991), p. 62.

${ }^{41}$ A.W Widajaja, Ilmu Komunikasi Pengantar Studi (Jakarta:Bina Aksara, 1988), p. 61.
} 
Pesan itu harus mengandung kebenaran yang sudah teruji, berdasarkan fakta dan tidak berisi kebohongan (hoaks);

\section{Concise}

Pesan itu lengkap dan tidak mengurangi arti sesungguhnya;

\section{Comprehensive}

Pesan itu mencakup keseluruhan dan maknanya sangat penting untuk diketahui oleh komunikan;

\section{Concrite}

Pesan itu nyata dan dapat dipertanggungjawabkan berdasarkan fakta dan data.

\section{Complete}

Pesan itu lengkap dan tersusun secara sistematis. ${ }^{42}$

Formulasi pesan moderasi beragama di Facebook harus mencerminkan pesan yang informatif dan persuasif. Informatif artinya pesan didasarkan pada data dan fakta, setidaknya penguna Facebook dapat membuat tagline atau postingan yang berisi informasi tentang nilai-nilai moderasi beragama. Berikutnya pesan tersebut harus memiliki daya pikat yang mempengaruhi atau mempersuasi emosi pembaca atau pengguna facebook yang lainnya. Pesan tidak mesti harus berbentuk tulisan, tapi bisa dalam bentuk video ataupun gambar ilustratif.

\section{F. Simpulan}

Massifnya radikalisme atas nama agama di Indonesia semakin meluas dan mendoktrinasi berbagai lapisan masyarakat. Ancaman itu juga tersebar melalui beragam media, baik media cetak, elektronik, bahkan media sosial. Oleh karena itu gagasan besar moderasi beragama di Indonesia harus disadari oleh seluruh umat beragama di Indonesia. Seluruh umat beragama juga memiliki peran yang sama untuk mengkampanyekan moderasi beragama di media apapun. Salah satunya di media Facebook. Kampanye moderasi beragama dapat dilakukan dengan ikut membuat pesan yang informatif dan persuasif, baik berupa pesan tertulis, gambar ilustratif atau video edukasi berdurasi pendek.

Para pengguna Facebook di Indonesia mempunyai potensi yang besar untuk ikut mengkampanyekan pesan moderasi beragama. Bahkan mereka bisa menginisiasi untuk

\footnotetext{
${ }^{42}$ Siahaan, Komunikasi Pemahaman dan Penerapannya, p.65
} 
| ARI WIBOWO | Kampanye Moderasi Beragama di Facebook: ...

membuat komunitas virtual yang konsen terhadap upaya moderasi beragama di Indonesia. Penulis juga berharap kajian ini bisa menstimuli pengguna media sosial dan akademisi lainnya untuk menyempurnakan kajian ini. 


\section{Daftar Pustaka}

Al-Alamah al-Raghib Al-Asfahaniy, Mufradat al-Fadz al-Qur"an, Beirut: Darel Qalam, 2009.

Arifin, Hasnul, Nongkrong Asyik di Internet Dengan Facebook, Jakarta: Buku Kita, 2009.

A.W Widajaja, Ilmu Komunikasi Pengantar Studi, Jakarta: Bina Aksara, 1988.

Bakri, Syamsul "Islam dan Wacana Radikalisme Agama Kontemporer," Jurnal DINIKA, vol. 3 no. 1, 2004, p. 10-12.

Choir, Tholhatul Choir, Ahwan Fanani, dkk, Islam Dalam Berbagai Pembacaan Kontemporer, Yogyakarta: Pustaka Pelajar, 2009.

Esposito, Jhon L., Unholy War:Teror Atas Nama Islam, Yogyakarta: Ikon, 2003.

Hanafi, Muchlis, Moderasi Islam: Menangkal Radikalisasi Berbasis Agama Jakarta: PSQ, 2013.

Harto, Kasinyo, "Pengembangan pembelajaran PAI Berwawasan Islam Wasatiyah: Upaya Membangun Sikap Moderasi Beragama Peserta Didik", Jurnal At-Ta'lim Media Informasi Pendidikan Islam, vol.18 no.1, 2019, p. 89-110.

Ibnu Asyur, at-Tahrir Wa at-Tanwir, Tunis: ad-Dar Tunisiyyah, 1984.

Kementerian Agama RI, Moderasi Beragama, Jakarta: Badan Litbang dan Diklat Kementerian Agama RI, 2019.

Kementerian Komunikasi dan Informatika Republik Indonesia, "BNPT: Internet jadi Media Penyebarluasan Terorisme", Kementerian Komunikasi dan Informatika RI, 9 Mei 2019, https://kominfo.go.id/content/d etail/18602/bnpt-internet-jadi-mediapenyebarluasanterorisme/0/ berita satker, diakses 20 Nov 2019.

Kompas, "Inilah Deretan Aksi Bom Bunuh Diri di Indonesia," KOMPAS.com, 14 Mei 2018, https://nasional.kompas.com/read/2018/05/14/13533731/inil ahlmderetanaksi-bom-bunuh-diri-di-indonesia, diakses pada 18 Nov 2019.

Kurniawan, Noor Hidayat, "Menag Luncurkan Buku Moderasi Beragama” (08 Okt2019), Direktorat Jenderal Bimbingan Masyarkat Islam (Bimas Islam), https://bimasislam.kemenag.go.id/post/berita/menag-luncurkan-buku-moderasiberagama, diakses pada 15 Nov 2019.

Laisa, Emna, "Islam dan Radikalisme”, Jurnal Islamuna, vol. 1 no. 1, 2014, p. 2.

Maulana, Dirga Maulana, "Ruang Moderasi Beragama”, Media Indonesia, 21 Jan 2019, https://mediaindonesia.com/read/detail/211781-ruang-moderasi-beragama, diakses 15 Nov 2019. 
| ARI WIBOWO | Kampanye Moderasi Beragama di Facebook: ...

Misrawi, Zuhairi, Hadratussyaikh Hasyim Asy'ari Moderasi, Keutamaan, dan Kebangsaan, Jakarta: Kompas Media Nusantara, 2010.

Mussafa, Rizal Ahyar, Konsep Nilai-nilai Moderasi dalam Al-Qur'an dan Implementasinya dalam Pendidikan Agama Islam (Analisis al-Qur'an surat alBaqarah 143), Skripsi, Fakultas Ilmu Tarbiyah dan Keguruan Universitas Islam Negeri Walisongo Semarang: 2018, p. 20.

Nasrullah, Rulli, Etnografi Virtual, Bandung: Simbiosa, 2017.

Nasrullah, Rulli, Komunikasi Antar Budaya Di Era Budaya Siber, Bandung: Simbiosa, 2012.

Nur, Afrizal dan Mukhlis, "Konsep Wasathiyah dalam Al-Qur'an (Studi Kompartif Antara Tafsir At-Tahriri Wa At-Tanwir dan Aisar At-Tafsir"), Jurnal An-Nur, vol.4 no. 2, 2015, p. 205-223.

Piliang, Yasraf, Bayang-Bayang Tuhan: Agama Dan Imajinasi (Bandung: Mizan Publika. 2011.

Pratikno, Globalisasi Komunikasi, Jakarta: Pustaka Sinar Harapan, 1987.

Qustulani, Muhammad Fahmi Irfani, dkk, Moderasi Beragama: Jihad Ulama Menyelamatkan Umat dan Negeri dari Bahaya Hoax, Tangerang: PSP Nusantara: 2019.

Rohayati, "Proses Komunikasi Masyarakat Cyber Dalam Perspektif Interaksi Simbolik", Jurnal RISALAH, vol. 28, no. 1, 2017, p. 43-54.

Ruslan, Rosady, Manajemen Public Relatoins \& Media Komunikasi, Jakarta: Raja Grafindo Persada, 2008.

Sancaya, Rengga, “Anggota Muslim Cyber Army Ungkap Jadwal Perang Mereka di Medsos”, DetikNews, 11 Mar 2018, https://news.detik.com/berita/d-3910139/anggota-muslimcyber-army-ungkap-jadwal-perang-mereka-di-medsos, diakses 13 Nov 2019.

Setu, Fernandus, "Kominfo Blokir 11.803 Konten Radikalisme dan Terorisme", Kementerian Komunikasi dan Informatika Republik Indonesia, 15 Mar 2019, https:// kominfo.go.id/content/detail/17274/siaran-pers-no-63hmkominfo032019-tentangkominfo-blokir-11803-konten-radikalisme-dan-terorisme/0/siaran_pers, diakses pada 14 Nov 2019.

Sari, Reni Puspita, "Pencapaian Masyarakat Informasi Ditinjau Melalui Implementasi Program Kelompok Informasi Masyarakat (Kim): Studi Kasus Implementasi Program Kim Di Jawa Timur Di Wilayah Rural (Kim Nglanduk Dan Kim Warurejo) Dan Wilayah Urban (Kim Mojo Dan Kim Swaraguna)", Jurnal Berkala Ilmu Perpustakaan dan Informasi, vol. 13, no. 1, 2017, p. 56-63. 
Siahaan, S. M., Komunikasi Pemahaman dan penerapannya. Jakarta: Gunung Mulia, 1991.

Subdit Sarpras dan Kemahasiswaaan, "BNPT: Hati-hati radikalisme di kalangan Mahasiswa capai angka 20,3\%, Direktorat Pendidikan Tinggi Keagamaan Islam, 25 Nov 2013, https://iktis.kemenag.go.id/NEW/index.php?berita=detil\&jenis=news\&jd=162, diakses 13 Nov 2019.

Sobur, Alex, Semiotika Komunikasi, Bandung : Penerbit Remaja Rosdakarya, 2003.

Suharto, Toto, "Indonesianisasi Islam: Penguatan Islam Moderat dalam Lembaga Pendidikan di Indonesia", Jurnal Al-Tahrir: Jurnal Pemikiran Islam, vol. 17, no.1, 2017, p. 155-178.

Uchjana Effendi, Onong, Ilmu Komunikasi Teori dan Praktek, Bandung: Remaja Rosdakarya, 2002.

Venus, Antar, Manajemen Kampanye, Bandung: Simbiosa Rekatama Media, 2010.

Venus, Antar, Manajemen Kampanye: Panduan Teoritis dan Praktis dalam Mengefektifkan Kampanye Komunikasi, Bandung: Simbiosa Rekatama, 2004.

Wahid Foundation, Paparan Hasil Survei Nasional: Potensi Intoleransi dan Radikalisme Sosial-Keagamaan di kalangan Muslim Indonesia, tahun 2016.

Winarni, Leni, "Media Massa dan Isu Radikalisme Islam”, Jurnal Komunikasi Massa, vol.7 no.2 (2014) 